\title{
Maternal Attitude in the Handling of Diarrhea in Infant
}

\author{
Desta Ayu Cahya Rosyida ${ }^{1}$, Nina Hidayatunnikmah ${ }^{2}$ \\ ${ }^{1}$ Correspondence Author: desta@unipasby.ac.id \\ ${ }^{1}$ Faculty of Health Sciences of PGRI Adi Buana, Surabaya, Indonesia \\ 2 Faculty of Health Sciences of PGRI Adi Buana, Surabaya, Indonesia
}

\section{N D E X I N G}

Keywords:

Maternal Attitude;

Diarrhea;

Infant;

Kata Kunci:

Sikap Ibu;

Diare;

Bayi;

\begin{abstract}
A B S T R AC T
Diarrhea According to epidemiological theory is influenced by 3 factors, namely host, Agent and environment. The host is a landlady or as it is occupied for instance age, nutritional status. Diarrhoea disease in infants whose nutritional status is bad is more difficult to heal because of the damaged intestinal mucosa in the process of a longer revitelization. From the Government Health Service data of Jember District, in May 2008 the number of Diarrhea suffered reaches 4,601. In January 2008, the number of diarrhea sufferers reached 5,202 people, February 5,361, March 4,754, and April 4,755 sufferers. Of these, people less then 5 years old reach 70 percent. The purpose of this research to Analyzed attitude of mother in the treatment of diarrhea in infant in the health center of Arjasa District Regency of Jember. Research method used cross sectional study. The population of this study was toddlers with diarrhea of 58 children. Non-probability sampling technique with consecutive sampling types (which meet the inclusion and exclusion criteria).The information regarding maternal attitude was obtained by quistonnaire. Statistic test used descriptive analysis. Analysis results indicate that mothers with positive attitude find 26-35 years old, the last education of Junior and Senior High School, job as a housewife. Based on 35 samples, it shows that mothers with a positive attitude is 27 and mothers with negative attitude is 8 . The results of this study are maternal have positive attitude to give ORS on handling diarrhea in Infant.
\end{abstract}

Penyakit diare menurut teori epidemiologi dipengaruhi oleh 3 faktor yaitu host, agent, dan environment. Host merupakan induk semang atau yang ditempati misalkan umur dan status gizi. Penyakit diare pada balita yang status gizinya buruk lebih sulit disembuhkan karena vili mukosa usus yang risak mengalami proses repitelisasi. Data dari Dinas Kesehatan Kabupaten Jember, pada Mei 2008 jumlah penderita diare mencapai 4.601 orang. Januari 2008 jumlah penderita diare mencapai 5.202 orang, Februari 5.361, Maret 4.754, dan April 4.755 penderita. Dari jumlah tersebut, penderita dibawah umur 5 tahun mencapai 70\%. Tujuan dari penelitian ini adalah untuk menganalisis sikap ibu dalam penanganan diare pada balita di Puskesmas Arjasa Kabupaten Jember. Metode penelitian menggunakan cross sectional. Populasi penelitian merupakan seluruh balita yang terkena diare yaitu 58 balita. Pengambilan sampel menggunakan teknik non probability sample yaitu consecutive sampling (sesuai kriteria inklusi dan eksklusi). Data sikap ibu didapatkan dengan menggunakan kuisoner. Analisis statistik yang digunakan adalah deskripsi analisis. Hasil analisis menunjukan bahwa Ibu yang memiliki sikap positif rata-rata berada pada usia 25-35 tahun, pendidikan terakhir SMP dan SMA, dan pekerjaannya ibu rumah tangga. Berdasarkan dari 35 sampel didapatkan bahwa ibu dengan sikap positif sebanyak 27 dan sikap negatif sebanyak 8 ibu. Hasil penelitian ini menujukan bahwa ibu memiliki sikap yang positif dalam pemberian ORS pada penanganan diare. (C) 2020 JMMR. All rights reserved

Article History: Received 2019-12-31; Revised 2020-01-14; Accepted 2020-04-23

\section{INTRODUCTION}

Diarrhea According to epidemiological theory is influenced by 3 factors, namely host, Agent and environment. The host is a landlady or that is occupied for instance age, nutritional status is one of the most important host factors to do with diarrhea. In poor nutritional status or less nutrition, the human immune system is susceptible to illness or infection, including diarrhea. Diarrhoea disease in infants whose nutritional status is bad is more difficult to heal because of the damaged intestinal mucosa in the process of a longer repitelization so that food absorption by the intestinal mucosa villi is reduced. Agent is a 
carrier and environment is a good environment of physical, biological and socio-economic environment (Rusli, 2007).

Diarrhea is one of the world's health problems that should be a global concern. Based on WHO data, it is reported that there are almost 1.7 billion occurring in the world each year (Almatsier, 2014). Diarrhea is the main cause of the second death of children after the lumbering of $11 \%$ of all children under 5 years of age health problem that often occurs in Indonesia as a tropical area is diarrhea (Banerjee dkk., 2004). Extraordinary events (KLB) still often occur with a Case Fatality Rate (CFR) that is still high. Nearly 9 million children aged $<5$ years pass each year due to diarrhea (Datta dkk., 2001).

Nutritional Status is a state of the body as a result of food consumption and the use of nutritional substances. Nutritional status is distinguished into poor nutritional status, less, good and more. The nutrition is a health disorder due to the deficiency or imbalance of nutrients needed for growth, thinking activity and all things related to life. Weight loss is one of the most used anthropometry because these meters are easy to understand even by those who are illiterate. For the weight can be used as a valid size, other parameters such as height, frame size, proportion of fats, muscles, bones, and components. "Pathological weight" (e.g. edema or splenomegaly) should be considered. In other words, the weight should be recommended with the parameter Anthropometry (Naseem, 2016).

Diarrheal disease occupies the third order of mortality after perinatal $(23 \%)$ and acute respiratory infections (18\%). The deaths of diarrhea increased in 2002 by $15 \%$ compared to 2000 and 2001 which were only $13 \%$. In Indonesia as many as 8.4/1,000 toddlers died in 2002 (Almatsier, 2014). In East Java estimated number of diarrhea sufferers about $10,097,201$ people from the population of East Java of 35,679,156 inhabitants.

Oral Rehydration Solution (ORS) being simplest economical, effective therapeutic intervention for prevention and treatmenof dehydration has emerged as a magic pation in $20^{\text {th }}$ century ini managemen of diarrheas (Banerjee dkk., 2004). Despite this it is felt that ORS propaganda is not adequately transferred to community resulting inadequate, erratic or incomplete ORS therapy during dehydration. A number of studies have also reported the importance of home handling of diarrhea with ORS (Datta dkk., 2001).

Recording in another research have seen that knowledge and attitude mother to give ORS inadequate in some areas, grossly deficient. These attitude were mainly influenced by social and culture beliefs (Naseem, 2016). Another research was found mother used of ORS for management of diarrhea was found inadequate. Thought many mothers are aware that it useful most are not aware of its method of use (Mahor, 2013).

Spread of diarrhea disease in Jember district is very concern. From the data in the Public Health Office (Dinkes) Regency of Jember, in May 2008 the number of diarrhea sufferers reaches 4,601 people. The amount began to decline compared to the previous month. In January 2008, the number of diarrhea sufferers reached 5,202 people, February 5,361, March 4,754, and April 4,755 sufferers. Of these, people under 5 years old reach 70 percent. According to the description of head of health department of Jembe district, the emergence of diseases caused by the bacteria Escherichia Coli (E. coli) is due to several factors. Among other things, food consumed is less hygienic and the public does not maintain environmental health (Mahor, 2013). The caregiver specially the mother can play an important role in the management of diarrhea at home. Hence the awareness of mothers 
regarding the disease and its home managemeni is of outmost importance. With this background, the present study was conducted to research about mother attitude in the treatment of diarrhea in children in the health center of Arjasa Jember District.

The contribution of health research is especially focused on the incidence of diarrhea in infants has supported the awareness of mothers to be positive about the handling of diarrhea in children so that there is no more severe diarrhea. This Health research also shows that there are several factors characteristic of mothers that can be based on Mother's attitude in the handling of diarrhea in infants.

\section{RESEARCH METHOD}

The type research in this study uses descriptive quantitative and the design was "cross sectional". The design uses Indicates that there is a between attitudes and behavior or characteristics in the level of high. A person's attitude toward something can affect the expression coherently. Therefore good and positive education received can affect the establishment of a positive attitudesectional where researchers only measure one time during observation(Arikunto, 2010). The population of this study was toodlers with diarrhea of 58 children. Non probability sampling technique with consecutive sampling types. The large sample in this study amounted to 35 samples, of which large samples were obtained by a large number of blackred samples as well as adjusting with the inclusion and exclusion criteria(Notoadmojo, 2012). (1)Inclusion criteria a) mothers who have toddler affected diarrhea b) mothers willing to be responden c) not-illiterate mothers. (2) Exclusion criteria a) infants who are not affected by diarrhea b) mother who are not willing to be examined c) mothers who can not read and write. Information on data mothers was obtained by using quisoner and information data on infant who are affected by diarrhea from Health Center of Arjasa District Regency of Jember. Analysis data in this study used univariat Analysis, and bivariat Analysis(Sugiyono, 2013)

\section{RESULT AND DISCUSSION}

Based on table 1 . The characteristic of mother who have toddler affected by diarrhea include age, education, and occupation. In addition, their age mostly found at 19-25 years old (29\%), 25-35 years old (54\%), and >35 years old (17\%). Mostly, their highest education are senior high school (46\%), junior high school (31\%), and elementary school (17\%), and college school (6\%). Meanwhile their occupation are mostly housewives (40\%), civil servants $(36 \%)$, private $(29 \%)$, and farmer $(25 \%)$. Most mothers with diarrhea infant have a positive attitude towards the treatment of diarrhea is $77 \%$, and that has a negative attitude $23 \%$.

Table 1. Characteristics of Respondents by Age toward Respondents' Attitudes

\begin{tabular}{|l|l|c|c|c|c|c|c|}
\hline \multirow{2}{*}{ No } & \multirow{2}{*}{ Respondents ' age } & \multicolumn{4}{|c|}{ Mother Attitude } & \multicolumn{2}{c|}{ Total } \\
\cline { 3 - 8 } & & \multicolumn{2}{|c|}{ Positive } & \multicolumn{2}{c|}{ Negative } & \multicolumn{2}{c|}{} \\
\cline { 2 - 8 } & & $\sum$ & $\%$ & $\sum$ & $\%$ & $\sum$ & $\%$ \\
\hline 1 & $19-25$ & 7 & $20 \%$ & 3 & $9 \%$ & 10 & $29 \%$ \\
\hline 2 & $26-35$ & 15 & $43 \%$ & 4 & $11 \%$ & 19 & $54 \%$ \\
\hline 3 & $>35$ & 5 & $14 \%$ & 1 & $3 \%$ & 6 & $17 \%$ \\
\hline \multicolumn{2}{|c|}{ Total } & 27 & $77 \%$ & 8 & $23 \%$ & 35 & $100 \%$ \\
\hline
\end{tabular}


In this study the most maternal age at the age of $25-35(54 \%)$, where the age was a productive age. At the age of reproductive will make it easier for someone to receive information and gain more experience so that it will tend to be positive. Personal relics should leave a strong impression, therefore, attitudes will be easier to form when the personal experience occurs in situations involving the emotional factor of the more mature the person will be more and more experience Personally acquired so that the formation of attitudes will also be better(Azwar, 2005)

Tabel 2. Characteristics of respondents based on education on respondents ' attitudes

\begin{tabular}{|c|c|c|c|c|c|c|c|}
\hline \multirow{3}{*}{ No } & \multirow{3}{*}{ Respondents ' education } & \multicolumn{4}{|c|}{ Mother Attitude } & \multirow{2}{*}{\multicolumn{2}{|c|}{ Total }} \\
\hline & & \multicolumn{2}{|c|}{ Positive } & \multicolumn{2}{|c|}{ Negative } & & \\
\hline & & $\sum$ & $\%$ & $\sum$ & $\%$ & $\sum$ & $\%$ \\
\hline 1 & Elementary & 5 & $14 \%$ & 1 & $3 \%$ & 6 & $17 \%$ \\
\hline 2 & Junior High School & 10 & $29 \%$ & 1 & $3 \%$ & 11 & $31 \%$ \\
\hline 3 & Senior High school & 10 & $29 \%$ & 6 & $17 \%$ & 16 & $46 \%$ \\
\hline 4 & College & 2 & $6 \%$ & - & - & 2 & $6 \%$ \\
\hline & Total & 27 & $77 \%$ & 8 & $23 \%$ & 35 & $100 \%$ \\
\hline
\end{tabular}

The table 2. Respondents in this study mostly from the education group was a high school of 16 respondents (46\%). The higher a person's education will be more and more knowledge that will form a positive attitude in the face of a health problem. According to others researches which relates to attitudes Indicates that there is a between attitudes and behavior or characteristics in the high of level. A person's attitude toward something can affect the expression coherently. Therefore good and positive education received can affect the establishment of a positive attitude. The positive attitude occurred could be intrinsic drive, belief causing action, and behavior in positive way by themselves (van der Zwaluw dkk., 2013). Previous research results in Nigeria have shown that maternal education is an important predictor of diarrhea in children aged 0-24 months in Nigeria. While care should be made available to all children, strategies for reducing diarrhoea disease in children in Nigeria should focus more on uneducated children and less educated mothers. This study has provided a basis for future intervention studies that can inform the formulation and policy review in Nigeria towards prevention of diarrhea and its control (Desmennu dkk., 2017).

The work of the respondents of this study is the most domestic housewife (40\%), not working mothers will spend more time on children so that the elements of culture and environment will make the mother more posistive in handling Diarrhea. The work will form attitudes based on environmental or cultural conditions, the culture in which we live and raised has a great influence on the formation of our attitudes. We have a certain pattern of attitude and behavior because we have reinforcement (reinforcement, reward) from the community for such attitudes and behaviors, not for other attitudes and behaviors(Azwar, 2005). Previous research shows that maternal education and the social economic status of mothers play an important role is to ensure their children's knowledge, attitudes and practices on acute diarrhoea disease(Mutalik \& Raje, 2017) 
A person's attitude toward a particular problem is influenced by a variety of key factors including personal appreciation, the influence of important people, culture, mass media, educator institutions, and religious institutions, and emotional factors. Based on the results of bivariate analysis found the relationship between mother attitude to the incidence of diarrhea(The World Bank, 2006). According to previous study was found 74,2\% mothers used ORS to treat diarrhea at home(Saikia, 2017) Similar observation was found less than half of the participants $(42,4 \%)$ were used homemade solution during diarrheal disease of their children(Workie dkk., 2018) Another previous research, most of the mothers have a good attitude in the treatment of diarrhea related to follow-up or predilation when the children of bowel movements are more watery than usual with the treatment of diarrhea with enough ORS.

Continuing feeding along with administration of oral rehydration therapy during each episode of diarrhea helps in the absorption of fluid from the gut into the bloodstream to prevent dehydration (Unicef. Who, 2011). Other research also show that diarrhea is not lethal it self, the improrer knowledge, poor practice, and negative attitude of mother and their misdirected approach towards its management and prevention leads to high degree of severe dhydration and lastly death. Awareness mother to be positive about the handling of diarrhea in children so that there is no more severe diarrhea(Hackett dkk., 2015),(Workie dkk., 2018).

The child with diarrhea is considered a common illness in society and therefore there are various perceptions of mothers related to the causes and management of diarrhea in infants. It takes an interactive communication strategy for mothers and health workers to facilitate ongoing positive changes in caring for toddlers taking into consideration the culture and resources (Masdiana dkk., 2010). The findings of other research show that maternal attitudes and practices are satisfactory about prevention and home-based management of infant diarrhoea disease. Therefore, health education, information dissemination, and community conversation must more be plan and implement to create positive attitudes and practices against the prevention and management diarrhea more better (Workie dkk., 2018).

Tabel 3. Characteristics of respondents based on Occupation on respondents ' attitudes

\begin{tabular}{|l|l|c|c|c|c|c|c|}
\hline \multirow{2}{*}{ No } & \multirow{2}{*}{ Respondents ' education } & \multicolumn{3}{|c|}{ Mother Attitude } & \multicolumn{2}{c|}{ Total } \\
\cline { 3 - 8 } & & $\sum$ & \multicolumn{2}{|c|}{ Positive } & \multicolumn{2}{c|}{ Negative } & \multicolumn{2}{c|}{} \\
\cline { 3 - 8 } & & $\sum$ & $\sum$ & $\%$ & $\sum$ & $\%$ \\
\hline 1 & Housewife & 5 & $14 \%$ & 1 & $3 \%$ & 6 & $17 \%$ \\
\hline 2 & Farmer & 10 & $29 \%$ & 1 & $3 \%$ & 11 & $31 \%$ \\
\hline 3 & Private & 10 & $29 \%$ & 6 & $17 \%$ & 16 & $46 \%$ \\
\hline 4 & Civil Servants & 2 & $6 \%$ & - & - & 2 & $6 \%$ \\
\hline \multicolumn{2}{|c|}{ Total } & 27 & $77 \%$ & 8 & $23 \%$ & 35 & $100 \%$ \\
\hline
\end{tabular}

Based on table 3. research made done in village Saung Naga work area UPTD Health Center of Tanjung Agung 2014 There is a relationship of diarrhea with the attitude of mother and there is a meaningful relationship with the incidence of diarrhea with the action (Suparno \& Estiani, 2015). According to the assumption that the more positive a mother's attitude causes fewer babies who will experience diarrhea (Nasution \& Samosir, 2019). While 
other research conducted by Arsurya there is a relationship between mother behavior about the handling of diarrhea (Arsurya dkk., 2017).

\section{CONCLUSION}

In this study it can be concluded that the positive attitude possessed by respondents is quite a lot in dealing with diarrhea in the working area of the Arjasa Public Health Center in Jember Regency. Many mother have positive attitude who give ORS to the decision managem on diarrhea. Based on the age of the mother, most respondents have a positive attitude at reproductive age. The majority of respondents who were positive were respondents who had a junior high school education and above. Limitations in this study are that there are still a number of confounding factors, which in this study were not examined. Suggestions for further research can do a more complete and more in-depth study related to the high incidence of diarrhea in infants.

\section{REFERENCE}

Almatsier. (2014). Penatalaksanaan Diare. http://medicastore.com Arikunto, S. (2010). Metodologi Penelitian Kesehatan. Rineka Cipta.

Arsurya, Y., Rini, E. A., \& Abdiana, A. (2017). Hubungan Tingkat Pengetahuan Ibu tentang Penanganan Diare dengan Kejadian Diare pada Balita di Kelurahan Korong Gadang Kecamatan Kuranji Kota Padang. Jurnal Kesehatan Andalas, 6(2), 452. https://doi.org/10.25077/jka.v6i2.720

Azwar. (2005). Sikap manusia teori dan pengukurannya. Pusat Pelajar Offset.

Banerjee, B., Hazra, S., \& Bandyopadhyay, D. (2004). Diarrhea Management among under Fives. Indian Pediatrics.

Datta, V., John, R., Singh, V. P., \& Chaturvedi, P. (2001). Maternal knowledge, attitude and practices towards diarrhea and oral rehydration therapy in rural Maharashtra. Indian Journal of Pediatrics. https://doi.org/10.1007/BF02722350

Desmennu, A. T., Oluwasanu, M. M., John-Akinola, Y. O., Opeyemi, O., \& Ayo, A. S. (2017). Maternal education and diarrhea among children aged $0-24$ months in Nigeria. African Journal of Reproductive Health, 21(3), 27-36. https://doi.org/10.29063/ajrh2017/v21i3.2

Hackett, K. M., Mukta, U. S., Jalal, C. S. B., \& Sellen, D. W. (2015). Knowledge, attitudes and perceptions on infant and young child nutrition and feeding among adolescent girls and young mothers in rural Bangladesh. Maternal and Child Nutrition, 11(2), 173-189. https://doi.org/10.1111/mcn.12007

Mahor, G. R. (2013). Knowledge and attitudes of mothers regarding use of oral ehydration solution in management of diarrhea. Asian Journal of Biomedical and Pharmaceutical Sciences, 3(22), 6-8.

Masdiana, Tahlil, T., \& Imran. (2010). Persepsi , Sikap , \& Perilaku Ibu Dalam Merawat Balita Dengan Diare Mothers ' Perceptions , Attitudes \& Behaviors On Caring Children With Diarrhea. Jurnal Ilmu Keperawatan (2016), 4, 101-112.

Mutalik, A. V., \& Raje, V. V. (2017). Relationship between maternal education and socioeconomic status on knowledge, attitude and practice of mother and her child 
regarding acute diarrhoeal diseases. International Journal Of Community Medicine And Public Health, 4(12), 4472. https://doi.org/10.18203/2394-6040.ijcmph20175155

Naseem, A. (2016). Knowledge attitude and practice of childhood diarrhea and ORS administration in diarrhea amongst mothers of children below age 5 years. J Pediatr, 3(6), 416-420.

Nasution, Z., \& Samosir, R. F. (2019). Pengetahuan dan sikap ibu tentang penanganan diare di puskesmas polonia medan. Jurnal Darma Agung Husada, 5(1), 46-51.

Notoadmojo, S. (2012). Metode Penelitian Kesehatan. Rineka Cipta.

Rusli. (2007). Current Isue Kematian Anak Karena Diare. ridwanamiruddin.wordpress.com. https://ridwanamiruddin.wordpress.com/2007/10/17/current-issue-kematian-anakkarena-penyakit-diare/

Saikia, R. G. \& P. (2017). Knowledge, attitude and practices regarding diarrhoea and its managemen at home among mothers of under-five children residing within a subcentre area in Dibrugarh District, Assam. Scholars Journal of Applied Medical Sciences (SJAMS), 5(11C).

Sugiyono. (2013). Statistika Untuk Penelitian. Alfabeta.

Suparno, S., \& Estiani, M. (2015). Faktor-Faktor Yang Berhubungan Dengan Kejadian Diare Pada Balita di Kelurahan Saung Naga Kecamatan Baturaja Barat Tahun 2014. Jurnal Keperawatan Sriwijaya, 2(1), 22-29.

The World Bank. (2006). Theories of Behavior Change. 1990, 1-6. https://doi.org/10.4236/health.2013.53A078

Unicef. Who. (2011). Why Children Are Still Dying and What can be done.

van der Zwaluw, C. S., Kleinjan, M., Lemmers, L., Spijkerman, R., \& Engels, R. C. M. E. (2013). Longitudinal associations between attitudes towards binge drinking and alcohol-free drinks, and binge drinking behavior in adolescence. Addictive Behaviors. https://doi.org/10.1016/j.addbeh.2013.01.012

Workie, H. M., Sharifabdilahi, A. S., \& Addis, E. M. (2018). Mothers' knowledge, attitude and practice towards the prevention and home-based management of diarrheal disease among under-five children in Diredawa, Eastern Ethiopia, 2016: A crosssectional study. BMC Pediatrics, 18(1), 1-9. https://doi.org/10.1186/s12887-018$1321-6$ 